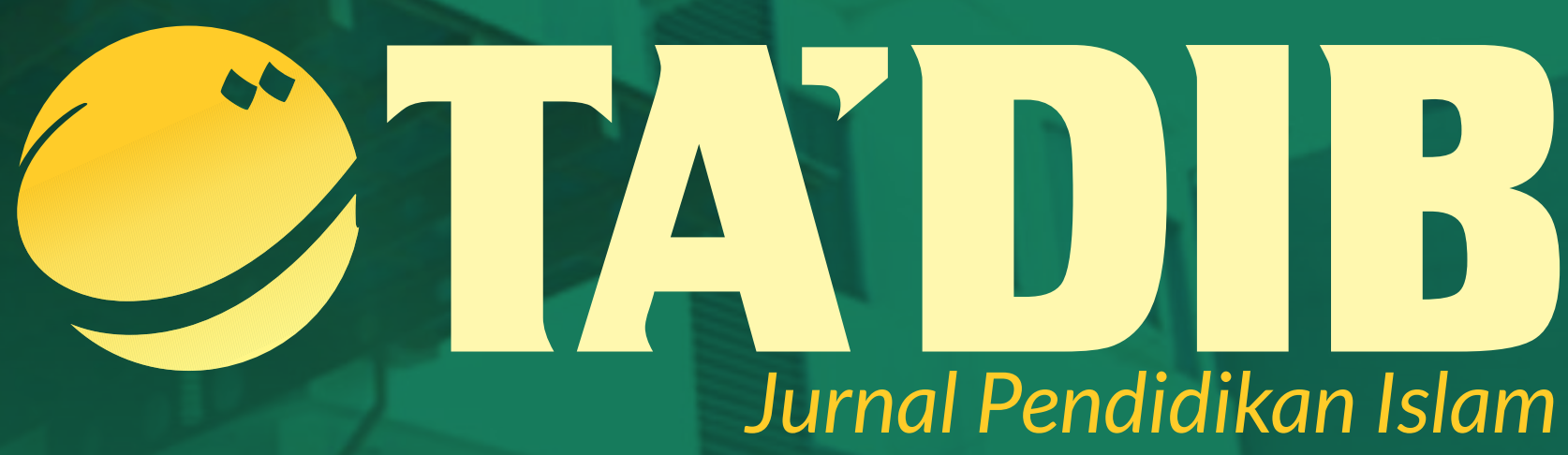

Implementasi Penilaian Otentik dalam Pembelajaran PAI Berbasis Multiple Intelligences di Sekolah Dasar Islam Terpadu Buahati Jakarta Alhamuddin

Kepemimpinan Kyai Dalam Menjaga Tradisi Pesantren Helmi Aziz, Nadri Taja

Gaya Kepemimpinan Kepala Madrasah dalam Meningkatkan Mutu Layanan Pendidikan Bashori

Model Pesantren Kewirausahaan di Era Kompetisi

Hasbi Indra

Model Pengembangan Kreativitas Melalui Permainan Konstruktif (PKPK) dalam Meningkatkan Kemampuan Berpikir Kreatif Anak Usia Dini

Masnipal

Pengembangan Nilai-nilai Agama dan Moral di Taman Kanak-Kanak

Arif Hakim

Implementasi Pembentukan Karakter pada Peserta Didik di MI Asih Putera Kota Cimahi

Enoh, Khambali

Analisis Pembelajaran Pendidikan Agama Islam di STIK Bina Husada Palembang

Maryance

Perilaku Prososial Remaja dalam Perspektif Bimbingan Konseling Islami

Nurul Afrianti, Dian Anggraeni

Perbandingan Implementasi Pendekatan Saintifik pada Pembelajaran PAI di SMP Negeri 5 Bandung dan SMP Negeri 51 Bandung

Yuyun Juariah

Konsep Pendidikan Anak dalam Islam Untuk Mencegah Kejahatan dan Penyimpangan Seksual Siska Lis Sulistiani

Kontribusi Pendidikan Agama Islam terhadap Perubahan Sikap Keagamaan Mahasiswa Di STIK Bina Husada Palembang

Rahmi Musaddas
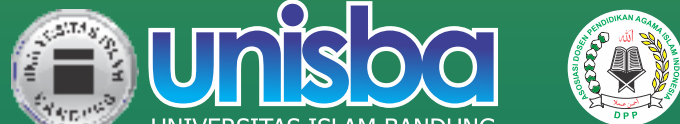

FAKULTAS TARBIYAH DAN KEGURUAN UNIVERSITAS ISLAM BANDUNG 


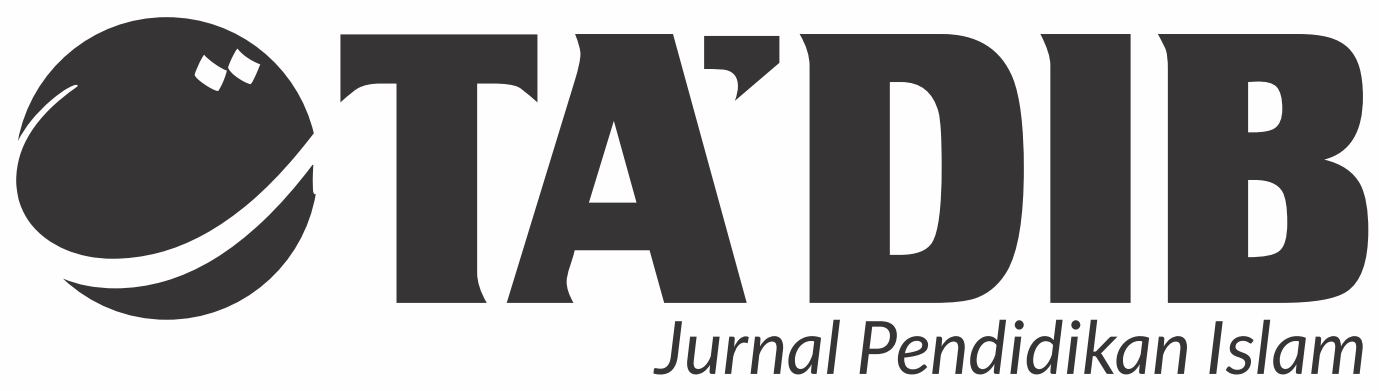

Jurnal Ta'dib terbit pertama kali pada februari tahun 2000 sampai November 2004 dengan ISSN 1411-8173 yang diterbitkan oleh Fakultas Tarbiyah Unisba; Pada tahun 2008 berubah menjadi JPI (Jurnal Pendidikan Islam) dengan ISSN 1979-0163 yang diterbitkan oleh Fakultas Tarbiyah Unisba bekerja sama dengan Asosiasi Dosen Pendidikan Agama Islam Indonesia (ADPISI). Pada tahun 2016, Jurnal Ta'dib kembali diterbitkan dengan nama Ta'dib: Jurnal Pendidikan Islam dengan ISSN. 1411-8173 (Media Cetak) dan EISSN. 25285092 (Media Elektronik) oleh Fakultas Tarbiyah dan Keguruan Unisba bekerja sama dengan Asosiasi Dosen Pendidikan Agama Islam Indonesia (ADPISI). Jurnal ini terbit 2 (dua) kali dalam setahun, pada bulan Mei dan November. Berisi artikel yang diangkat dari hasil penelitian di bidang pendidikan Islam.

Harga Berlangganan:

Rp. 89.000/volume; Rp. 160.000/tahun

\section{Alamat Kantor:}

Sekretariat Fakultas Tarbiyah dan Keguruan Universitas Islam Bandung, Lantai 3.

Jln. Ranggagading No. 8 PO BOX 1357 Kota Bandung 40116

Telp. $085624018800-081321493108$

Website. http://ejournal.unisba.ac.id/index.php/tadib

Email. jurnaltadib@gmail.com 


\section{Daftar Isi}

Daftar Isi

PraTA'DIB

Implementasi Penilaian Otentik dalam Pembelajaran PAI Berbasis Multiple Intelligences di Sekolah Dasar Islam Terpadu Buahati Jakarta

Alhamuddin

Kepemimpinan Kyai Dalam Menjaga Tradisi Pesantren

Helmi Aziz, Nadri Taja

Gaya Kepemimpinan Kepala Madrasah dalam Meningkatkan

Mutu Layanan Pendidikan

Bashori....

Model Pesantren Kewirausahaan di Era Kompetisi

Hasbi Indra

Model Pengembangan Kreativitas Melalui Permainan Konstruktif (PKPK) dalam Meningkatkan Kemampuan Berpikir Kreatif Anak Usia Dini

Masnipal

Pengembangan Nilai-nilai Agama dan Moral di Taman Kanak-Kanak

Arif Hakim

Implementasi Pembentukan Karakter pada Peserta Didik di MI Asih Putera Kota Cimahi

Enoh, Khambali

Analisis Pembelajaran Pendidikan Agama Islam di STIK Bina Husada Palembang

Maryance

Perilaku Prososial Remaja dalam Perspektif Bimbingan Konseling Islami

Nurul Afrianti, Dian Anggraeni

Perbandingan Implementasi Pendekatan Saintifik pada Pembelajaran PAI di SMP Negeri 5 Bandung dan SMP Negeri 51 Bandung

Yuyun Juariah

Konsep Pendidikan Anak dalam Islam Untuk Mencegah Kejahatan dan Penyimpangan Seksual

Siska Lis Sulistiani

Kontribusi Pendidikan Agama Islam terhadap Perubahan Sikap

Keagamaan Mahasiswa Di STIK Bina Husada Palembang

Rahmi Musaddas

Petunjuk Penulis 


\section{PRATA'DIB}

Puji dan syukur kehadirat Allah Swt. yang telah melimpahkan karunia-Nya, sehingga Jurnal Ta'dib: Jurnal Pendidikan Islam Volume V Nomor 1 Tahun 2016 dapat hadir kembali di lingkungan Fakultas Tarbiyah dan Keguruan Universitas Islam Bandung setelah lama vakum dari aktivitas penerbitan.

Jurnal ta'dib merupakan arena atau ruang bagi pengungkapan gagasan dan pemikiran yang berkaitan dengan masalah-masalah pendidikan Islam, baik secara teoretis maupun praktis. Tulisan yang tampil dalam volume ini dibuka dengan perbincangan seputar masalah penilaian pada mata pelajaran pendidikan agama Islam di sekolah. Penulis menawarkan model penilaian otentik. Penilaian otentik merupakan salah satu bentuk penilaian yang tidak hanya menekankan pada hasil, namun juga memperhatikan aspek proses. Penilaian otentik menekankan paada perkembangan bertahap yang harus dilalui oleh peserta didik dalam mempelajari sebuah keterampilan atau pengetahuan. Teori ini menganjurkan sistem yang tidak bergantung pada tes standar atau tes yang didasarkan pada norma formal, akan tetapi mengacu pada kriteria tertentu atau ipsative (yaitu tes yang membandingkan prestasi peserta didik saat ini dengan prestasinya yang lalu).

Selain paparan mengenai penilaian otentik, dalam jurnal ini juga dipaparkan mengenai kepemimpinan madrasah dan pesantren dalam rangka meningkatkan layanan mutu pendidikan Islam. Gaya kepemimpinan merupakan salah satu faktor penentu terciptanya iklim pesantren dan madrasah yang kondusif dan kinerja sistem organisasi yang baik. Dalam lingkungan yang kondusif akan menciptakan mutu layanan pendidikan yang baik pula.

Di samping gaya kepemimpinan yang perlu diperhatikan oleh lembaga pesantren. Lembaga pesantren perlu tuntutan dan tuntunan di era perdagangan bebas. Saat ini era majunya ilmu pengetahuan dan teknologi memberikan kemudahan bagi kehidupan umat manusia dan juga memiliki dampak negatif terhadap norma agama dan nilai-nilai utama kehidupan umat manusia yang bersumber dari nilai ketuhanan. Karenanya pesantren harus memberikan perhatian yang lebih intens kepada para santrinya tentang urgensi pengembangan ekonomi syariah yang memberi keadilan dalam penyelenggaraan perekonomian dalam menciptakan kesejahteraan umat manusia dan semakin intens menyiapkan para santri dengan jiwa entrepreneurship serta berbagai skill untuk kehidupannya sehingga dapat bersaing di era perdagangan bebas.

Perhatian terhadap pendidikan anak usia dini juga diangkat dalam paparan volume ini. Model pengembangan kreativitas melalui permainan konstruktif (PKPK) dalam meningkatkan kemampuan berpikir kreatif anak usia dini. Beberapa temuan penelitian menunjukkan bahwa kemampuan berpikir kreatif anak-anak di Indonesia masih rendah dibanding dengan kemampuan kreatif anak-anak Negara tetangga semisal Malaysia, Singapore dan Brunei Darussalam. Penanaman kemampuan berpikir kreatif sejak dini akan sangat mendukung peningkatan kemampuan anak di usia berikutnya. Di samping kemampuan berpikir kreatif, pengembangan nilai-nilai agama dan moral perlu ditanamkan sejak dini kepada anak-anak.

Akhirnya redaksi mengucapkan terima kasih kepada para penulis yang telah menyumbangkan gagasan dan pemikirannya. Sehingga gagasan dan pemikiran yang dituangkan dalam Jurnal "Ta'dib" volume ini dapat membangun dialog yang lebih dalam dan dapat dijadikan rujukan dalam mengtasi persoalan-persoalan yang muncul di masyarakat khususnya pendidikan Islam.

Redaksi Ta'dib 
DAFTAR ISI 


\title{
MODEL PESANTREN KEWIRAUSAHAAN DI ERA KOMPETISI
}

\author{
HASBI INDRA ${ }^{1}$ \\ ${ }^{1}$ Universitas Ibnu Khaldun, Bogor \\ Email: hasbiindra58@gmail.com
}

\begin{abstract}
The research of qualitative methods are based of Islamic scholars by book or journals. This research is important because Islamic boarding school is one of institution to create the great people. Islamic boarding school now be a part of national systems and are hoped to reach national level and even international level quality. In that conditions Islamic boarding school are face of globalization fenomenon that are bear result development of science and give easy for humans life and also that contains negative effects such as break of values of human and then the norms of religion had stay. The development of economic effortt in the future in the world are interesting part for well of nation so dealt with a side in free trade among of Asian nation. In this era Islamic boarding school as institutional education are a parts its could attention for it. Islamic boarding school in the future could attention for horizon santri dealt with very interesting for human life specially about economic in which give justice deploy it and ethics for them in order to create of well of humanity and also give attention to readiness santri with souls entrepreneurship and skill for their life and then could compete by human being in this worlds.
\end{abstract}

Keywords: Islamic boarding school, economic, entrepreneurship.

\begin{abstract}
Abstrak
Penelitian model pesantren wirausaha merupakan penelitian kualitatif yang bersumber pada pemikiran ilmuan baik melalui buku maupun jurnal. Penelitian ini penting karena lembaga pendidikan pesantren salah satu pilar penting dalam mencerdaskan anak bangsa. Lembaga pesantren telah menjadi bagian dari sistem pendidikan nasional harus siap menghadapi era perdagangan bebas. Saat ini era majunya ilmu pengetahuan dan teknologi memberikan kemudahan bagi kehidupan umat manusia dan juga memiliki dampak negatif terhadap norma agama dan nilai-nilai utama kehidupan umat manusia yang bersumber dari nilai ketuhanan. Karenanya pesantren harus memberikan perhatian yang lebih intens kepada para santrinya tentang urgensi pengembangan ekonomi syariah yang memberi keadilan dalam penyelenggaraan perekonomian dalam menciptakan kesejahteraan umat manusia dan semakin intens menyiapkan para santri dengan jiwa entrepreneurship serta berbagai skill untuk kehidupannya sehingga dapat bersaing di era perdagangan bebas.
\end{abstract}

Kata Kunci: pesantren, ekonomi, dan entrepreneurship.

\section{Pendahuluan}

Pesantren merupakan salah satu lembaga penting untuk membangun bangsa Indonesia di masa mendatang. Pendidikan pesantren dalam perkembangannya telah ikut serta mengatasi berbagai problem bangsa dalam berbagai bidang kehidupan, sejak era orde lama, orde baru hingga era reformasi sekarang ini. Eksistensi pesantren semakin kokoh dengan adanya Undang-Undang Sistem Pendidikan Nasional No. 20 tahun 2003 dan Peraturan Pemerintah No. 55 tahun 2007. Undang-undang dan peraturan tersebut memuat Pendidikan Agama dan Pendidikan Keagamaan Islam. Salah satu yang ada di dalamnya mengatur pendidikan pesantren.
Hal ini kemudian yang menjadi cikal bakal ditetapkannya Keputusan Menteri Agama (KMA) No. 18 tahun 2014 yang mengatur tentang pesantren mu'adalah.

Pendidikan pesantren sebagai pendidikan "asli" nusantara telah berperan dalam membangun bangsa Indonesia telah mengalami perkembangan. Perkembangan pesantren dilihat dari sistemnya terdiri atas tiga bentuk, yaitu pesantren tradisional atau salafiyah, pesantren kombinasi, dan pesantren modern atau 'asyriyah.

Pendidikan pesantren mengalami perkembangan sesuai dengan tantangan zamannya. Oleh sebab itu, pendidikan pesantren harus menyesuaikan diri dengan 
keadaan yang ada agar dapat berperan memecahkan persoalan masyarakat.

Indonesia pada masa mendatang seperti juga bangsa lain akan menghadapi persoalan eksistensi hidup. Untuk membangun dirinya, bangsa Indonesia selama tujuh puluh tahun lebih dari masa orde lama hingga masa reformasi sekarang mengandalkan sumber daya alam yang kaya berupa minyak yang melimpah ruah, emas, timah dan lainnya. Namun, kekayaan bangsa yang demikian itu tidak selamanya ada. Oleh sebab itu, diperlukan upaya pengoptimalan potensi sumber daya manusia salah satunya melalui peningkatan mutu pendidikan pesantren.

Menurut Azra pendidikan Islam termasuk pesantren belum memberikan peran yang maksimal dalam pembangunan bangsa (2005: 11). Selain itu, kualitas pendidikan nasional secara keseluruhan termasuk di dalamnya pendidikan pesantren masih berada di bawah negara-negara Asean seperti Singapura, Malaysia. Filipina, Thailand dan Vietnam (Muhammad, 2007: 164). Pendidikan pesantren saat ini berada di tengah era kompetisi antarbangsa yang dapat mengambil peran dalam meningkatkan kualitas pendidikan di tanah air serta mempersiapkan dirinya di era yang semakin menantang dan rumit ini. Oleh sebab itu, model lain dari pesantren perlu dikembangkan misalnya model pesantren kewirausahaan.

Penelitian tentang model pesantren wirausaha adalah penelitian kualitatif yang didasarkan pada studi literatur yang bersumber pada pemikiran ilmuan baik melalui buku, maupun jurnal. Peneliti berusaha mendeskripsikan kondisi yang dihadapi pesantren dan pentingnya pendidikan pesantren sebagai lembaga pendidikan yang berkualitas dalam menyiapkan para santri untuk memiliki mental wirausaha agar mampu bersaing dalam menghadapi era kompetisi.

\section{Tinjauan Pustaka Sejarah Perkembangan Pesantren}

Institusi pendidikan pesantren telah ada pada masa Walisongo pada abad ke-16 di daerah Gresik Jawa Timur. Kata pesantren berasal dari kata santri diambil dari dua suku kata yaitu sant (manusia baik) dan tra (suka menolang), yang bermakna tempat untuk membina manusia menjadi orang baik (Indra, 2009: 211). Sementara itu, kata santri berasal dari kata shastri atau shastra yang artinya orang yang menguasai bukubuku agama Hindu yang berkaitan dengan ilmu pengetahuan (Dhofier, 1994: 6). Dalam pandangan Dhofier pendidikan pesantren memiliki empat komponen, yakni masjid, kyai, santri dan kitab kuning sebagai materi kajian di pesantren (1994: 44).

Pendidikan pesantren pada awalnya hanya mengaji agama di beranda rumah ustadz atau kyai selain itu ada pula yang dilakukan di masjid. Dua tempat ini tidak cukup luas maka dibuatlah suatu tempat untuk belajar agama. Mereka yang belajar berasal dari tempat yang jauh untuk belajar kepada seorang kyai, maka dibuatlah tempat berdiam para santri yang kemudian lembaga pendidikan ini disebut dengan pesantren.

Dalam pendidikan pesantren, para santri dibentuk karakternya. Jujur, disiplin, kerja sama, mandiri dan lainnya merupakan beberapa karakter yang dikembangkan dalam pendidikan pesantren.

Jam belajar di pesantren dimulai setelah subuh hingga malam hari. Dengan cara ini ilmu yang didapatkan bisa banyak. Di samping itu, para santri dapat membiasakan diri dan mendapat contoh dari kyai atau ustadznya. Kemandirian mereka terbentuk karena semua keperluannya dikerjakan sendiri.

Sistem pesantren dikelompokkan menjadi tiga bentuk yaitu: (1) pesantren Salafiyah yang memfokuskan belajar ilmu agama melalui kitab kuning; (2) pesantren terpadu yaitu sistem pesantren yang para santrinya disamping belajar kitab kuning, juga bersekolah di sekolah formal seperti SLTP/SMU atau madrasah, dan; (3) pesantren Khalafiyah atau 'Asyriyah, yaitu sistem pesantren yang santrinya belajar ilmu agama dan ilmu umum, adapun mengkaji kitab kuning tidak dibebankan kepada santri (Indra, 2010: 3).

Salafiyah adalah pola awal pendidikan pesantren disebut dengan pesantren salafiyah yang kurang sentuhan terhadap prakarsa atau kurang mendorong kreativitas santri karena pola pembelajarannya kurang dialogis (Indra, 2009: 213). Padahal, sifat Allah Swt. yaitu pencipta perlu diteladani pada diri manusia yaitu kreativitas untuk mengembangkan ciptaan Allah Swt. di bumi (Qs. Ali Imran: 190, Qs. Al-Mukminun: 12).

Sumber belajar di pesantren salafiyah adalah kitab kuning. Para santri dibimbing oleh seorang kyai, mereka belajar masalah akidah, ibadah, dan muamalah kemudian ditambah dengan pelajaran-pelajaran seperti mantiq, balaghah, faraidl dan bidang lainnya. (Indra, 2009: 214). Belajar kitab kuning melalui 
tingkatan-tingkatan yang ditentukan oleh kyai, mulai dari tingkat awal hingga tingkat lanjutan selama mereka belajar di pondok. Cara belajarnya dengan model sorogan, yaitu santri belajar langsung secara individu kepada kyai dengan cara mendengarkan bacaan dan pemahamannya, dan juga melalui cara bandongan yaitu santri belajar secara berkelompok kepada kyai dengan cara mereka mencatat penjelasan sang kyai di sisi kitabnya atau memberi arti di bawah teks kitabnya. Juga, dengan cara halaqah yakni santri belajar bersama, mendiskusikan suatu masalah untuk dicarikan solusi bersama-sama (Indra, 2010: 2).

Kedua, sistem pesantren terpadu, yaitu sistem pesantren yang para santrinya di samping belajar kitab kuning mereka juga bersekolah di sekolah formal seperti SLTP/ SMU atau madrasah. Sistem pesantren terpadu dipengaruhi oleh sistem pendidikan penjajah, yaitu tempat belajar di kelas, ada tingkatan-tingkatan, belajar ilmu umum dan agama, ada evaluasi dan lulusannya diberi ijazah. Inilah tonggak dinamika yang substantif di pesantren (Azra, 1998: 87).

Ketiga, pesantren Khalafiyah atau 'Asyriyah, yaitu sistem pesantren yang santrinya belajar ilmu agama dan ilmu umum, adapun mengaji kitab kuning tidak dibebankan kepada santri. Pesantren yang menyebut dirinya 'Asyriyah atau modern awalnya berdiri di Ponorogo Jawa Timur. Santrinya belajar ilmu agama dan non agama, santri memiliki skill bahasa Inggris atau bahasa Arab, karena dua bahasa tersebut dijadikan bahasa pengantar pendidikan dan diwajibkan sebagai bahasa sehari-hari, serta keterampilan lainnya seperti keterampilan memimpin, keterampilan menulis, dan sebagainya. Pesantren 'Asyriyah dan juga beberapa pesantren lain memperoleh pengakuan pemerintah dalam bentuk mua'dalah (Zarkasyi, 2005: 99).

Pengakuan pemerintah dalam bentuk mu'adalah karena produknya telah mendapatkan pengakuan di berbagai negara Timur Tengah, di samping banyak tokoh telah berkiprah di tanah air menjadi pemikir ilmu keislaman antara lain: Mukti Ali, Nurcholish Madjid dan lainnya yang menjadi tokohtokoh agama organisasi besar seperti di Muhammadiyah yaitu Din Syamsuddin dan tokoh Nahdlatul Ulama yaitu Hasyim Muzadi. Begitu pula kiprah mereka di politik dan di birokrasi pemerintahan, Hidayat Nurwahid dan Lukman Hakim Syaifuddin. Mereka adalah produk pendidikan pesantren yang kurikulumnya didesain sendiri oleh pengelolanya. Dengan kiprah para alumni dan kiprah lulusannya yang menonjol di berbagai pendidikan tinggi Islam di luar negeri, akhirnya secara institusi mendapat pengakuan dari pemerintah. Dengan ijazahnya mereka dapat bergerak bebas baik melanjutkan pendidikannya maupun kiprahnya di dunia pekerjaan dan di masyarakat.

Pemerintah melalui Anggaran Pendapatan dan Belanja Negara (APBN) memberikan dana bantuan untuk pengembangan pesantren. Hanya saja dana bantuan pemerintah jumlahnya kecil dan terbatas, untuk pengembangan lebih lanjut tentu saja tergantung kepada masing-masing pesantren. Dengan dana yang terbatas, pesantren tetap terus mengalami pengembangan dan perubahan. Perubahan ini merupakan suatu keniscayaan karena di pesantren memegang kaidah al-muhafazhatu 'ala al-qadimi al-shalih wa al-akhdzu al-jadidi al-ashlah/ memelihara khazanah lama yang baik dan mengambil yang baru yang baik (Indra, 2010: 217).

Perubahan yang mesti terjadi di pesantren agar berkontribusi dalam pembangunan bangsa, maka para santrinya harus dibekali bukan saja ilmu agama tetapi juga ilmu umum, seperti matematika dan pengetahuan alam juga wawasan kewirausahaan dan keterampilan untuk bekal hidupnya di tengah masyarakat.

Perubahan atau pengembangan pesantren perlu terus dilakukan karena berada dalam pusaran pendidikan nasional yang kualitasnya masih berada di peringkat terendah dibawah negara-negara Asean seperti Singapura dengan skor 3.19; Malaysia, 4.41; Philipina, 5.47; Thailand, 5.96; Vietnam, 6.21 dan Indonesia, 6.56 (Muhammad, 2007: 166). Padahal di antara negara-negara tersebut seperti Malaysia pernah belajar ke Indonesia untuk meningkatkan kualitas pendidikannya.

\section{Perekonomian dalam Islam}

Peningkatan mutu pendidikan di pesantren tentu memerlukan pendanaan yang berkaitan dengan perputaran perekononomian. Perekonomian telah banyak digambarkan ayat-ayat al-Qur'an dan juga telah ditunjukkan oleh Nabi Muhammad Saw. (Bastoni, 2013: 141). Al-Qur'an mengisyaratkan begitu penting kegiatan ekonomi atau mencari rezeki, sehingga Allah Swt. berfirman: "Sesungguhnya Aku (Allah Swt.) telah memuliakan keturunan Adam (manusia), Aku angkut mereka di daratan dan di lautan, Aku beri mereka rezeki dari yang baik-baik, dan 
Aku lebihkan mereka dengan kelebihan yang sempurna atas kebanyakan makhluk yang Aku ciptakan" (Qs. al-Isra': 7). Kemudian dalam ayat yang lain dinyatakan: "Apabila telah ditunaikan shalat, maka bertebaranlah kamu sekalian di muka bumi dan carilah karunia Allah Swt. (yakni rezeki/harta) dan ingatlah kepada Allah Swt. banyak-banyak agar kamu beruntung" (Qs. al-Jumu'ah: 10).

Ayat-ayat tersebut menunjukkan bahwa rezeki diperoleh tidak dengan cara berdiam diri di rumah atau hanya berdoa, tanpa adanya upaya yang keras (ikhtiyar), namun harus dilakukan dengan kerja keras. Adanya ungkapan bertebaran, memberi petunjuk kepada upaya ikhtiyar, juga memberi petunjuk bahwa kekayaan tidak hanya terbatas pada jenis-jenis tertentu namun sangat luas, umum dan berkembang sesuai dengan kemampuan yang telah ditekuni, dan dapat pula diambil pengertiannya, bahwa dalam mencari rezeki Allah Swt., jangan melupakan Allah Swt. serta melalui cara-cara yang dibenarkan.

Kegiatan manusia dalam berekonomi didorong oleh naluri manusia yang diberikan Allah Swt., yakni memiliki kecintaan terhadap harta dan perhiasan, seperti yang dijelaskan dalam al-Qur'an yang artinya: "Allah Swt. Swt. telah menjadikan naluri manusia kecintaan kepada lawan seksnya, anak-anak, serta harta yang banyak berupa emas, perak, kuda piaraan, binatang ternak, sawah dan ladang" (Qs. Ali Imran: 14).

Selain ayat-ayat di atas, ada pula ajaran Islam yang berkaitan dengan zakat, infak dan sadaqah, hal-hal itu mengisyaratkan bagi seseorang memiliki harta yang lebih dari kebutuhan primernya untuk dikeluarkan. Dengan kata lain, infaq, sadaqah dan zakat baru terwujud dengan kekayaan dan kekayaan bisa diperoleh dengan cara kerja keras dan dengan skill yang dimiliki.

Al-Qur'an lebih jauh menjelaskan tentang uang atau maal dan pengembangannya dalam kegiatan ekonomi yang di dalam al-Qur'an disebut sebanyak 25 kali dalam bentuk tunggal dan amwal dalam bentuk jamak sebanyak 61 kali. Kata tersebut mempunyai dua bentuk. Pertama, tidak dinisbatkan kepada pemilik, dalam arti dia berdiri sendiri. Ini adalah sesuatu yang logis, karena memang ada harta yang tidak menjadi obyek kegiatan manusia, tetapi berpotensi untuk itu. Kedua, dinisbatkan kepada sesuatu seperti harta mereka, harta anak yatim, harta kamu dan lain-lain, ini adalah harta yang menjadi obyek kegiatan dan bentuk inilah yang terbanyak digunakan Al-Qur'an. Uang diartikan sebagai harta kekayaan dan nilai tukar bagi sesuatu. Berbeda dengan dugaan sementara orang yang beranggapan bahwa Islam kurang menyambut baik pentingnya uang pada hakikatnya pandangan Islarn terhadap uang dan harta amat positif (Shihab, 1998: 405).

Manusia diperintah Allah Swt. untuk mencari rezeki bukan hanya untuk mencukupi kebutuhannya, tetapi al-Qur'an memerintahkan untuk mencari apa yang diistilahkan "kelebihan" ( $f a d l$ ) yang secara harfiyah berarti kelebihan yang bersumber dari Allah Swt.. Salah satu ayat yang mendukung itu terdapat dalam surat alJumu'ah, ayat 10 yang telah penulis jelaskan. Kelebihan itu dimaksudkan antara lain agar dimanfaatkan untuk melakukan ibadah secara sempurna serta mengulurkan tangan/bantuan kepada pihak lain karena satu dan lain sebab tidak berkecukupan atau untuk mendirikan masjid, atau peringatan Hari Besar Islam, dan kegiatan lainnya.

Dalam kaitan harta dan uang dinilai qiyaman, yaitu sarana pokok kehidupan (Qs. an-Nisa': 5). Tidak heran Islam memerintahkan untuk menggunakan uang secara baik serta tidak memboroskannya. Bahkan memerintahkan untuk menjaga dan memelihara hingga al-Qur'an melarang pemberian harta kepada pemiliknya sekalipun, apabila sang pemiliknya boros atau tidak dapat mengurus harta secara baik.

Dalam konteks ini, al-Qur'an berpesan kepada mereka yang diberi amanat memelihara harta seseorang (Qs. an-Nisa' : 5), "janganlah kamu memberi orang-orang yang lemah kemampuan (dalam pengurusan harta) harta (mereka yang ada di tangan kamu dan yang dijadikan Allah Swt. sebagai sarana pokok kehidupan)". Dalam konteks ini, uang dalam pandangan al-Qur'an merupakan modal serta salah satu faktor produksi yang juga penting. Manusia menduduki tempat di atas modal disusul sumber daya alam. Pandangan ini berbeda dengan pandangan sementara pelaku ekonomi modern yang memandang uang sebagai segala-galanya sehingga tidak jarang sumber daya -baik itu sumber daya alam maupun manusiadieksploitasi sewenang-wenang.

Modal dalam kegiatan ekonomi sangat penting dan tidak boleh diabaikan manusia. la berkewajiban menggunakannya dengan baik agar ia terus produktif karena itu seorang wali yang menguasai harta orang-orang yang tidak atau belum mampu mengurus hartanya diperintahkan untuk mengembangkan harta yang berada di dalam kekuasaannya dan 
membiayai kebutuhan pemiliknya yang tidak mampu itu, dari keuntungan perputaran modal. Ini dipahami dari redaksi ayat alQur'an (an-Nisa: 5), yang menyatakan wardzukuhum fiha bukan wardzukuhum minha. Minha artinya dari modal, sedang fiha berarti di dalam modal yang dipahami sebagai ada sesuatu yang masuk dari luar ke dalam (keuntungan) yang diperoleh dari usaha. (Shihab, 1998: 406). Oleh sebab itu, modal tidak boleh menghasilkan dari dirinya sendiri, tetapi harus dengan usaha manusia. Ini salah satu sebab mengapa membungakan uang dalam bentuk riba dan perjudian dilarang oleh al-Qur'an. Salah satu hikmah pelarangan riba serta pengenaan zakat sebesar 2.5 persen terhadap uang (walau tidak diperdagangkan) adalah untuk mendorong aktivitas ekonomi, perputaran dana serta sekaligus mengurangi spekulasi serta penimbunan seperti pada surat at-Taubah ayat 34 yaitu "Dan orangorang yang menyimpan emas dan perak dan tidak menafkahkan pada jalan Allah Swt. maka beritahukanlah kepada mereka bahwa mereka akan mendapat siksa yang pedih".

Ekonomi selama ini seolah hanya persoalan zakat, infaq dan shadaqah. Tema rezeqi hanya dipahami kecukupan makan yang sudah diatur oleh Allah Swt.. Rezeqi memang bagian dari takdir Allah Swt. selain kematian dan jodoh. Tetapi, rezeqi spektrumnya luas, rezeqi yang lebih dari hasil upaya atau ikhtiyar juga diperkenankan alQur'an. Beberapa negara Muslim beruntung karena tanahnya memiliki minyak, mas, perak, gas dan lainnya. Akan tetapi, banyak negara yang mayoritas muslim sulit hidupnya karena tidak bisa mengolah sumber daya alamnya dan juga tidak ada ikhtiyar lain. Negara-negara Muslim Afrika hidup hanya berfikir bagaimana mempertahankan akidah agama tetapi tidak berfikir bagaimana mempertahankan kehidupannya yang layak.

Muslim banyak mengandalkan nasibnya kepada negara, agar negara memberi makan pada mereka, tetapi tidak memikirkan bagaimana memberdayakan negara agar dapat memenuhi keinginan mereka. Masyarakat Madinah sering disebut oleh kaum ilmuan sebagai masyarakat madani, masyarakat yang memberdayakan dirinya sendiri tanpa bergantung dukungan negara untuk mencapai kesejahteraannya, ini sebenarnya yang harus dicontoh. Muslim saat ini sudah tidak menemukan lagi jejak-jejak Ibnu Sina, Ibn Rusyd dan kini tidak juga menemukan Abu Bakar, Usman yang kaya raya, kalau pun ada hanya sedikit (Muhammad, 20014: 141).
Kemiskinan dipandang suatu takdir dan ada yang mengkahawatirkan kalau muslim kaya akan menjadi fitnah, ia akan lupa Tuhannya. Padahal, kekayaan juga berpotensi bagi Muslim untuk mengeluarkan zakat yang besar atau mengeluarkan shadaqahnya untuk kepentingan syiar Islam. Muslim mengalami nestapa karena tidak memiliki kekayaan, mareka dihancurkan karena tidak memiliki kekayaan atau tidak memiliki apa apa untuk mempertahankan keyakinan dan bahkan hidupnya.

Pada dekade ini muslim telah mulai berfikir bagaimana memberdayakan instrumen perekonomian melalui ikhtiyar membangun perekonomian umat manusia. Ekonomi Islam Indonesia mendapatkan momentum yang baik dengan didirikannya Bank Muamalah dan saat ini hampir semua bank konvensional memiliki bank syariah (Hafiduddin \& Tanjung, 2011: 10). Perguruan tinggi Islam maupun umum telah membuka program studi ekonomi syariah. Bank yang menggunakan sistem yang Islami ini akan semakin berkembang di era kompetisi.

Untuk hal itu memerlukan Muslim yang memiliki kualitas dalam menghadapi persaingan dunia kerja dengan segenap kompetensinya. Al-Qur'an menyatakan, "Janganlah muslim memberikan amanah kepada orang yang lemah" (QS. An-nisa': 9). Tentang kompetensi salah satu diisyaratkan oleh Nabi Saw. agar generasi muda Muslim menyiapkannya, yaitu: "apabila suatu amanah diberikan ke orang yang bukan ahlinya tunggulah kehancurannya" (Abu Abdillah, 1987: 33).

\section{Pembahasan \\ Model Pesantren Berbasis Wirausaha}

Pesantren hidup di tengah dinamika demikian cepat terutama dalam bidang ilmu pengetahuan dan teknologi serta perubahan budaya masyarakat yang semakin sekularistik, hedonistik dan konsumtif. Di tengah perubahan ini pesantren harus menghadirkan manusiamanusia yang berkualitas. Tuntutan agar produknya berkualitas merupakan tuntutan dari firman Allah Swt. bahwa "Muslim hendaklah menjadi umat yang terbaik yang memanggil kepada kebaikan dan mencegah kemungkaran" (QS. Ali Imran, 110). Kualitas yang dimiliki dengan menguasai ilmu (Indra, 2016: 117) dan menguasai perekonomian.

Ekonomi bagian dari gambaran al-Qur'an yang harus diupayakan oleh muslim dalam kehidupannya, "Sesungguhnya Aku (Allah 
Swt.) telah memuliakan keturunan Adam (manusia), Aku angkut mereka di daratan dan di lautan, Aku beri mereka rezeki dari yang baik-baik, dan Aku lebihkan mereka dengan kelebihan yang sempurna atas kebanyakan makhluk yang Aku ciptakan" (QS. al-Isra': 7). Kemudian dalam ayat yang lain dinyatakan: "Apabila telah ditunaikan shalat, maka bertebaranlah kamu sekalian di muka bumi dan carilah karunia Allah Swt. (yakni rezeki/harta) dan ingatlah kepada Allah Swt. banyak-banyak agar kamu beruntung" (QS. al-Jumu'ah: 10). Kualitas-kualitas itu harus dimiliki oleh produk pendidikan pesantren apalagi di era kompetisi dan era kebijakan perdagangan bebas antar negara Asia yang disebut dengan masyarakat ekonomi Asean (Baskoro, 2015).

Ekonomi telah menjadi bagian dari kehidupan siapapun termasuk umat muslim yang harus diraihnya dengan jiwa entrepreneurship. Jiwa entrepreneurship harus mewarnai produk pendidikan pesantren kalau mereka ingin memberi warna terhadap kehidupan di era kompetisi. Di era kompetisi, manusia menerima informasi sangat cepat melalui berbagai media, baik cetak, elektronik maupun media sosial. Dalam konteks ini Madjid berpandangan bahwa dunia saat ini one worked one globe (Arifin, 2014: 171).

Pengembangan di bidang IPTEK terjadi di bidang kedokteran, angkasa luar, dan sebagainya sehingga memudahkan manusia memenuhi kebutuhan hidupnya (sandang, pangan, papan, fasilitas belajar, berobat dan sebagainya). Namun, di sisi lain berdampak negatif seperti pencemaran limbah industri, kesenjangan antara yang kaya dan miskin kian menganga serta efek negatif lainnya (Ibrahim, 1995: 18).

Pandangan hidup konsumerisme dan hedonisme telah melanda umat manusia, maka disinilah perisai mentalitas menjadi sangat penting. Sisi lain, adanya pengintegrasian ekonomi nasional kepada sistem ekonomi dunia (Faqih, 2005: 210), seperti NAFTA perjanjian dagang antar Amerika dengan Meksiko, dan Sijori antara Singapura, Johor dan Riau Indonesia. (Faqih, 2006: 196). Juga tingkat regional telah terbentuk Masyarakat Ekonomi Asean di mana bangsa Indonesia harus siap menghadapinya. (Baskoro, 3 Oktober 2015).

Era kompetisi menjadi tantangan langsung bagi pendidikan pesantren untuk menyiapkan lulusannya agar dapat bersaing dengan produk pendidikan lainnya di Indonesia maupun produk pendidikan luar negeri. Di era kompetisi, produk pendidikan pesantren disiapkan menjadi petarung di tengah gelombang nilai-nilai yang acap kali bertentangan dengan nilai-nilai Islam. Selain itu kompetensi lulusannya harus menguasai Information of technology (IT) (Nata, 2008: 254). Hal lain pula yang perlu disiapkan adalah kepercayaan dirinya bergaul dengan dunia internasional, kepercayaan diri bukan saja karena memiliki segudang ilmu atau memiliki keahlian yang mumpuni tetapi kepercayaan diri karena mereka memiliki kemampuan berkomunikasi dalam bahasa internasional.

Tenaga pengajar sangat berperan, guru atau ustadz merupakan seorang motivator, menggerakkan santrinya untuk siap bertarung. Jangan sampai seorang ustadz melewatkan kesempatan untuk memberi motivasi kepada para santrinya. Pemberian motivasi kepada para santri sangat diperlukan untuk meningkatkan kualitas dirinya di era kompetisi. Sebagaimana Allah Swt. sendiri melalui ayat-ayatnya menjadikan motivasi sebagai pendorong kepada Muslim agar memiliki ilmu pengetahuan yang akan mengangkat derajatnya (QS. al-Mujadalah, 11).

Berbagai kondisi harus dihadapi pesantren. Oleh sebab itu, pesantren hendaklah memberikan nilai-nilai positif untuk meningkatkan kualitas diri para santrinya guna menghadapi dan juga menyiapkan mereka untuk menyonggsong era kompetisi. Melalui gerakan memperkokoh ekonomi Islam juga membentuk para entrepreneurship di pondok pesantren. Ekonomi syariah yang berkeadilan perlu terus dikembangkan dalam bentuk instrumen keuangan yang dapat dikembangkan di pendidikan pesantren. Para santrinya sejak dini sudah harus diberikan wawasan tentang ekonomi Islam dalam wawasan ekonomi kontemporer sehingga mereka memiliki pandangan begitu pentingnya ekonomi Islam ditegakkan dalam kehidupan umat manusia yang semakin materialistik dan sekularistik ini.

Dengan demikian pendidikan pesantren harus juga menyiapkan lulusannya menjadi entrepreneurship yang di masyarakat bidang ini demikian luasnya kesempatan bagi mereka (Soemahamidjaya, dkk., 2011: 2). Mereka setelah lulus harus mampu menciptakan pekerjaaan sendiri dan tidak bergantung ke pihak lain.

Nabi Saw. sendiri mencontohkan dalam kehidupannya mencari rezeqi tanpa kenal lelah. Nabi melakukan perdagangan ke 
negeri yang jauh dari kota Makkah yakni kota yang sekarang ini dikenal dengan Negara Suria. Sekaligus nabi menunjukkan jiwa entrepreneurshipnya sejak muda. Nabi Saw. memandang begitu pentingnya menguasai ekonomi untuk mengembangkan ajaran Islam sehingga nabi menyunting Khadijah, janda kaya serta nabi dalam mengembangkan ajaran Islam didukung oleh para shahabat yang kaya seperti Abu Bakar dan lainnya (Muhammad, 20014: 141).

Selain itu ekonomi bagian yang penting dalam kehidupan ini, sejak manusia lahir sudah beraitan dengan ekonomi untuk mempertahankan dan mengembangkan kehidupannya. Bahkan seperti yang telah digambarkan beberapa ayat al-Qur'an tersebut di atas serta uswatun hasanah dari Nabi Muhammad Saw. yang meraih ekonomi secara gigih tanpa mengenal lelah untuk menjalani hidup serta mengembangkan syiar Islam. Tanpa diraih hal itu, syiar Islam mustahil akan terus bersinar. Mental yang dimiliki oleh Nabi Saw. adalah mental entrepreneurship.

Pendidikan pesantren harus menyiapkan santri yang berkualitas. Institusi ini tidak cukup lagi hanya sebagai tempat pengawetan nilai-nilai agama yang ditanamkan pada anak didik, tetapi mereka harus lebih dari itu. Pesantren di era mendatang yang jumlahnya dalam kisaran 29.535 ribu untuk semua jenisnya dan santri sebanyak 3.876.696 dan guru atau ustadz yang jumlahnya lebih kurang 160 ribu harus menyiapkan diri menghadapi era kompetisi. (Direktorat Jenderal Pendidikan Islam, 2014: 88). Mereka tidak hanya cukup telah belajar sains dan teknologi (QS. alJatsiyah, 13) juga harus disertai dengan mental wirausaha.

Mental wirausaha di negara lain sudah lama digalakkan terutama di negara-negara yang sangat sedikit memiliki sumber daya alamnya, seperti Negara Jepang (www. merdeka.com, 8 Januari 2016), Korea Selatan, (www.bisnis.tempo.co., 8 Januari 2016), dan Singapura. (www.republika, 8 Januari 2016). Negara Jepang, negara yang kalah perang pada waktu perang dunia II, negara di mana dua kotanya Nagasaki dan Hirosima hancur rata dengan tanah, tanahtanah mereka menjadi tidak subur karena bom. Begitu pula dengan Korea Selatan, negara yang pernah perang dengan sesama saudara yaitu Korea Utara, karena rebutan ideologi komunis dan non komunis, negaranya pun hancur. Begitu pula dengan Singapura, negara yang kecil yang tidak memiliki sumber daya alam yang ada hanya sumber daya manusia. Mereka menyadari bahwa manusia sejak dulu dalam kurun apapun tetap hidup karena memiliki potensi yang luar biasa di dalam dirinya. Mereka belajar dari sejarah perjalanan kehidupan manusia, sementara orang muslim bukan saja dapat belajar dari sejarah perjalanan manusia tetapi dapat belajar dari kitab sucinya.

Al-Qur'an bercerita bagaimana Nabi Nuh As. dapat menyelamatkan umatnya dari banjir besar yang mengancam nyawa umatnya dengan membuat kapal. (Tentang Nabi Nuh, lihat al-Qur'an Surah Nuh 5-12, 26-27 dan Hud, 41-48. Bagaimana Siti Hajar dan anaknya Nabi Ismail As. yang ditinggal suaminya Nabi Ibrahim As. atas perintah Allah Swt. (QS. Ibrahim 37 dan al-Baqarah, 158) (lihat www.eramuslim.com; lihat pula http://perkarahati.wordpress.com, lihat pula islamiwiki.blogspot.co.id). Bagaimana Nabi Muhammad Saw. menghidupi dirinya di masa remaja hingga masa kenabiannya, dan mensyiarkan Islam dan menyebarkan Islam dengan sumber daya manusia melalui mental kewirausahaan (Bastoni, 2013: 141).

Mental wirausaha harus dimiliki oleh produk pendidikan pesantren, karena Indonesia yang memiliki sumber daya alam yang potensial seperti gas, minyak bumi, emas, timah dan lainnya akan habis. Indonesia dengan penduduk yang demikian besar dan sementara sumber daya alam akan habis, untuk itu diperlukan sumber daya manusia yang memiliki jiwa wirausaha, maka kondisi ini mengharuskan pesantren meninjau visi dan misinya saat ini. Apalagi para santri tidak semua akan menjadi pemikir agama atau pemimpin agama, umumnya mereka akan kembali ke masyarakat yang tentu jiwa enterpreneurship jawabannya. Kalau tidak, mereka tidak dapat berkompetisi dengan produk pendidikan lain. Bahkan mereka tidak mampu menolong dirinya sendiri apalagi menolong orang lain.

Indonesia ke depan memerlukan banyak wirausahawan untuk menjaga eksistensinya, muslim bagian dari eksponen yang harus membantu tegaknya negara dan juga menopang syiar Islam yang tentunya memerlukan banyak dana yang berasal dari para wirausahawan, merupakan sumbangsih yang sangat besar apabila pesantren memperhatikan hal tersebut. Juga menjadi hal yang bermanfaat dan menjadi amal ibadah bagi para pengelolanya apabila dapat menyiapkan para santri memiliki jiwa enterpreneurship. Dengan keterampilan 
yang mereka miliki serta dengan jiwa enterpreneurship dan bahasa yang sudah fasih berkomunikasi dengan bangsa lain serta memiliki karakter baik yang teruji melalui pesantren akan sangat mudah merespon era kompetisi yang ada di hadapan mata.

Untuk itu pesantren harus mengembangkan visi dan misi pendidikannya bukan hanya mencetak ahli agama tetapi juga mencetak para santri yang berjiwa wirausaha. Para santri yang berjumlah 3.8 juta lebih tidak semua akan menjadi ahli agama, sebagian besar mereka akan berprofesi seperti masyarakat lainnya. Profesi lain sangat luas seperti profesi bidang pertanian, industri, peternakan, perkebunan dan lainnnya, namun bidang-bidang tersebut membutuhkan orang-orang yang memiliki keterampilan. Yang lebih diperlukan lagi adalah orang-orang yang memiliki jiwa entrepreneurship atau wirausahawan, mereka yang dapat menciptakan lapangan pekerjaan. Para wirausahawan ini memiliki jiwa mandiri yang tidak bergantung pada orang lain (Soemahamidjaya, dkk, 2011: 2).

Sebenarnya jiwa kemandirian telah menjadi bagian dari pendidikan pesantren. Para santri telah biasa mengurus keperluannya sendiri mulai dari mencuci pakaian sendiri, memasak sendiri dan memenuhi kebutuhan lainnya. Pendidikan pesantren memiliki potensi untuk mencetak para santri yang berjiwa wirausaha (Arief, 2011: 1-13). Hanya saja pada umumnya pesantren tidak mengembangkan jiwa kemandirian para santri ini sebagai bekal kehidupannya setelah menyelesaikan pendidikan di pesantren. Untuk itu, pesantren di samping memperbaharui visi dan misi pendidikannya juga membentuk para ustadz yang juga memberi motivasi agar santrinya memiliki jiwa kemandirian dalam kehidupan. Santri yang memiliki jiwa wirausaha kelak akan menjadi orang kaya dan melalui kekayaannya ia akan dapat mendirikan masjid, sekolah, rumah sakit dan lainnya sehingga amalnya melalui kekayaannya akan membawanya memperoleh surga di akhirat kelak.

Selain itu melalui mata pelajaran yang diberikan seperti pelajaran figh ibadah misalnya ketika membahas tentang haji, ustadz tidak hanya menjelaskan ada pahala bila melaksanakan atau akan seseorang diampuni dosanya dan kelak akan masuk surga. Tetapi yang penting dijelaskan bahwa haji itu memerlukan dana yang besar yang dana itu harus dicari melalui usaha dagang, begitu pula ketika menjelaskan tentang zakat, shadaqah, orang harus mencarinya terlebih dahulu baru dapat membayar zakat dan mengeluakan shadaqah, tanpa berusaha atau berdagang hal itu tidak dapat dipenuhi. Pendekatan pembelajaran dapat dilakukan di kelas atau di luar kelas atau di kegiatankegiatan lainnya seperti kegiatan peramuka, harus menjadi bagian dari penanaman jiwa wirausaha itu. Pemimpin pesantren juga harus memberi motivasi bagi santri pada setiap acara di pesantren tentang pentingnya santri memiliki jiwa wirausaha guna mendorong umat juga memiliki jiwa itu tersebut.

Pimpinan pesantren harus mendirikan usaha ekonomi di pesantrennya sebagai tempat untuk mengembangkan kemandirian pesantren dalam bidang ekonomi. Pemimpinnya hendaklah menggambarkan bahwa muslim harus mengusai ekonomi agar dapat membangun sekolah, masjid yang indah, dapat menyelenggarakan syiar Islam, dapat menyantuni yatim piatu, fakir miskin dan menghindarkan muslim dari perbuatan yang hina yakni menadahkan tangannya dipinggir jalan untuk membangun sekolah, masjid, menyantuni anak yatim dan itulah sebenarnya semangat dari hadits Nabi Saw. yang menyatakan al-yadul ulya kharun min al-yadu al-sufla--bahwa orang muslim tangannya harus di atas bukan di bawah.

Untuk mengamalkan hadist itu muslim di manapun harus memandang pengembangan ekonomi bagi umat Islam merupakan esensi ajaran al-Qur'an dan al-Hadits. Pendidikan pesantren merupakan lembaga pendidikan bagi muslim yang harus mengamalkan ajaran Islam tersebut melalui langkah-langkah yakni mengembangkan visi dan misinya. Kemudian para ustadznya harus memberikan motivasi kepada para santrinya agar memiliki jiwa wirausaha. Untuk membentuk jiwa itu melalui pendekatan pembelajaran misalnya yang berkaitan dengan menunaikan ibadah haji, menunaikan ibadah itu harus melakukan upaya berdagang dari berdagang akan memproleh laba dan laba semakin banyak ia menjadi kaya maka ia dapat menunaikan ibadah haji karena ia benar-benar orang mampu yang wajib melaksanakannya. Pemimpin pesantren juga harus memiliki semangat yang sama dengan para ustadznya dan di pesantrennya hendaklah didirikan tempat usaha sebagai pengembangan ekonomi dan tempat belajar santri dalam berwirausaha.

\section{Simpulan}

Pesantren di tanah air masih tetap eksis setelah melalui masa pemerintahan orde lama 
yang belum banyak memberi perhatian untuk mengembangkannya. Hingga era orde baru dan era reformasi baru memberikan perhatian yang memadai. Di masa reformasi melalui regulasi UU Sistem Pendidikan Nasional No. 20 tahun 2003 dan PP. No. 55 tahun 2007 tentang Pendidikan Agama dan Pendidikan Keagmaan Islam serta PMA No. 18 tahun 2014 tentang Satuan Pendidikan Mu'adalah. Institusi pesantren telah berada di dalam Sistem Pendidikan Nasional.

Di era ekonomi perdangan bebas, ketimpangan antar negara masih terjadi. Ketimpangan ini disebabkan oleh sistem ekonomi kapitalis yang tidak menempatkan keadilan dalam penyelenggaraan perekonomian. Ekonomi Islam berada di dalamnya harus terus dikembangkan agar dapat memberikan warna terhadap penyelenggaran perekonomian dunia.

Pesantren menyandang salah satu tugas itu dalam penyelenggaraan pendidikannya.

Lulusan pesantren harus memiliki jiwa entrepreneurship, suatu jiwa mandiri yang mampu berkompetisi dengan semangat tinggi dan tidak mengenal rasa putus asa. Dengan memiliki jiwa entrepreneurship, produk pesantren tidak gagap menghadapinya atau tidak menjadi penonton yang pasif. Di samping itu, para santri perlu memiliki skill dan penguasaan terhadap information of technology (IT) serta memiliki penguasaan bahasa internasional yang tentu saja sangat berguna untuk pergaulan antar bangsa.

Perwujudan pesantren berbasis wirausaha akan menghasilkan para santri yang berwawasan luas dan bermental wirausaha. Wirausahawan santri adalah orang-orang yang menciptakan lapangan pekerjaan dan calon-calon orang kaya yang menguasai ekonomi dan dengan kekayaannya mereka dapat mewarnai ekonomi nasional serta mendanai berbagai kegiatan syiar agama.

Lulusan pesantren akan siap mengantarkan umat Islam menjadi umat terbaik dan siap menghadapi era kompetisi. Untuk itu diperlukan pengembangan visi misi pendidikan pesantren, diperlukan pula ustadz yang selalu memberi motivasi para santri agar memiliki jiwa wirausaha melalui pendekatan pembelajaran tentang puasa, shalat, haji dan zakat yang memerlukan upaya manusia untuk memenuhi hal tersebut. Demikian pula pemimpin pesantren memiliki semangat yang sama dan mendirikan usaha perkekomoian di pesantrennya guna pengembangan ekonomi dan juga menjadi latihan para santri agar memiliki jiwa wirausaha.

\section{Daftar Pustaka}

Arifin, Syamsul. (2014). Strategi Pendidikan Dalam Rangka Menghadapi Globalisasi, Tarbiya, UIN Syarif Hidayatullah Jakarta, Vol. 2.

Arief, Zainal A. (2011). Pendidikan Kewirausahaan Sebagai Pilihan Meraih Sukses, Bogor: Widya Sakti,

Azra, Azyumardi. (1998). Esei-esei Intelectual Muslim dan Pendidikan Islam, Jakarta: Logos.

Baskoro, Aryo. (2015). Peluang, Tantangan dan Resiko bagi Indonesia dengan Adanya Masyarakat Ekonomi Asian, Center for Risk Management studies Indonesia, (CRMSI).

Bastoni, Andi Hepi. (2013). Beginilah Rasulullah Berbisnis, Bogor: Pustaka alBustan.

Dhofier, Zamakhsjari. (1994). Tradisi Pesantren, Jakarta: LP3ES.

Direktorat Jenderal Pendidikan Islam. (2014). Statistik Pendidikan Islam 2012-2013, Jakarta: Direktorat Jenderal Pendidikan Islam.

Faqih, Mansour. , (2005). Runtuhnya Teori Pembangunan dan Globalisasi, Yogyakarta: Insist Press.

(2006). Jalan Lain, Yogyakarta: Insist Press.

Hafiduddin, Didin \& Hendri Tanjung (2009). Shariah Perinciples on Management in Practice, Jakarta: Gema Insani.

Hajar, Siti. (2015). (Islamiwiki.blogspot. co.id), diunduh 2 Januari 2016.

Hati, Perkara. (2015). (http://perkarahati. wordpress.com) diunduh pada 2 Juli 2016

Ibrahim, Marwah Daud, (1995). Teknologi, Emansipasi dan Transendensi, Bandung: Mizan.

Indra, Hasbi. (2010). Manajemen Pendidikan Islam, Tawazun, Pascasarjana Univ. Ibn. Khaldun, Vol. 4 No. 4, pp. 120-130. (2009), Pesantren dan Peradaban, Jabal Hikmah, STAIN Jayapura, Vol. 2. No. 4 Juli, pp. 45-60. . (2016), Pendidikan Tinggi Islam dan Peradaban Indonesia, Jurnal Tahrir STAIN Ponorogo, Vol. 16 No. 1, pp. 64-73.

Ismail, Abu Abdullah Muhammad. (1987). al-Buchari al-Ja'fi al-Jami al-Sahih alMukhtasar, Beirut: Dar Ibn Katsir.

Mohammad, Thoyyib. (2007). Internasionalisasi Pendidikan, dalam Hasil ACIS, Kemenag.

Muhammad, Nasri. (2014). Kewirausahaan Santri, Jakarta: Citrayuda.

Nata, Abuddin. (2008). Membangun 
Keunggulan Pendidikan Islam Indonesia, Jakarta: UIN Press.

Redaksi. (2015). Era MEA Daya Saing Tenaga Kerja, Republika 15 September 2015.

Shihab, M. Quraish. (1998). Wawasan alQuran, Bandung: Mizan.

Soemahamidjaya, Soeparman, dkk. (2003). Pendidikan Karakter Mandiri dan Kewirausahaan, Bandung: Angkasa.

Tanpa nama. (2016). Kembangkan Wirausaha contek Korsel, Tersedia di Tempo, Bisnis. com. diunduh pada tanggal 8 Januari 2016.

Tanpa nama. (2016) Belajar dari Siti Hajar Bunda Nabi Ismail tertera dalam Al-quran surat Ibrahim, 37, Al-baqarah, 158, (www.eramuslim.com/belajar dari sitihajar-bunda-nabi-ismail) diunduh pada 3 Oktober 2015.

Tanpa nama. (2016). Indonesia Harus Contek Cara Jepang yang Jumlah Wirausahanya $10 \%$. (www.merdeka.com.) diunduh pada tanggal 8 Januari 2016.

Tanpa nama. (2016). Jumlah Wirausaha Singapura $7 \%$, Indonesia $1.65 \%$ dari Jumlah Penduduk. (www.republika.co.id) diunduh pada tanggal 8 Januari 2016.

Zarkasyi, Abdullah Syukri. (2005). Gontor \& Pembaharuan Pendidikan Pesantren, Jakarta, Rajagrafindo. 


\section{Mitra Bebestari}

Andi Hadiyanto, Universitas Negeri Jakarta, Indonesia Makhmud Syafei, Univeritas Pendidikan Indonesia, Indonesia Maulia Depriya Kembara, Universitas Pendidikan Indonesia, Indonesia Muhammad Turhan Yani, Universitas Negeri Surabaya, Indonesia Syahidin, Universitas Pendidikan Indonesia, Indonesia

K. A. Rahman, Universitas Jambi, Indonesia Supian, Universitas Jambi, Indonesia

Syukri Fathudin Achmad Widodo, Universitas Negeri Yogyakarta, Indonesia

Nan Rahminawati, Universitas Islam Bandung, Indonesia

Erhamwilda, Universitas Islam Bandung, Indonesia

\section{Penanggung Jawab \\ Enoh}

\section{Pemimpin Redaksi}

Khambali

\section{Editor}

Muhamad Imam Pamungkas, Universitas Islam Bandung, Indonesia

Alhamuddin, Universitas Islam Bandung, Indonesia

Helmi Aziz, Universitas Islam Bandung, Indonesia

Nadri Taja, Universitas Islam Bandung, Indonesia

Dinar Nur Inten, Universitas Islam Bandung, Indonesia

Vita Fitria, Universitas Negeri Yogyakarta, Indonesia

Abdul Malik Usman, Universitas Gajah Mada, Indonesia

\section{Editor Bahasa}

Dheka Dwi Agustiningsih, Universitas Islam Bandung, Indonesia Yuristia Wira Cholifah, Universitas Islam Bandung, Indonesia 


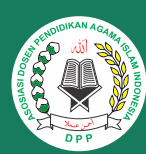

Alamat Kantor:

Sekretariat Fakultas Tarbiyah dan Keguruan

Universitas Islam Bandung, Lantai 3.

Jln. Ranggagading No. 8 PO BOX 1357 Kota Bandung 40116

Telp. $085624018800-081321493108$

Website. http://ejournal.unisba.ac.id/index.php/tadib

Email.jurnaltadib@gmail.com

eISSN. 2528-5092

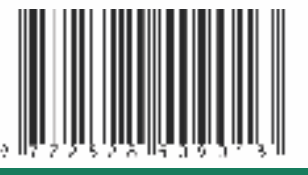

ISSN. 1411-8173

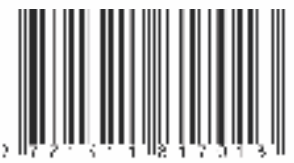

